\title{
Glutamate Dehydrogenase and 2-Oxoglutarate Reductase Electrophoretic Patterns and Deoxyribonucleic Acid- Deoxyribonucleic Acid Hybridization among Human Oral Isolates of Fusobacterium nucleatum
}

\author{
SAHEER E. GHARBIA* AND HAROUN N. SHAH \\ Department of Oral Microbiology, The London Hospital Medical College, London E1 2AD, England
}

\begin{abstract}
The electrophoretic mobilities of glutamate dehydrogenase and 2-oxoglutarate reductase were compared for three reference strains and $\mathbf{3 0}$ human, oral isolates of Fusobacterium nucleatum. Both enzymes allowed the same strains to be grouped into three electrophoretic clusters, designated groups Fn-1, Fn-2, and Fn-3. Group Fn-1 contained the type strain of $F$. nucleatum, strain ATCC 25586, and nine clinical isolates. Group Fn-2 comprised 20 strains and appeared to contain the strains of $F$. nucleatum that are isolated most commonly from oral cavities. Strain NCTC 10953 (formerly 'F usobacterium polymorphum') was a member of this cluster. Strains of group Fn-3 were rarely isolated; this group contained three isolates and reference strain NCTC 11362, which was listed previously as "Fusobacterium fusiforme." The deoxyribonucleic acid (DNA) base compositions of all strains were between 25 and $27 \mathrm{~mol} \%$ guanine plus cytosine. Under optimal conditions of DNA-DNA hybridization, all of the strains exhibited high levels of DNA homology (73 to 99\%) to the three reference DNA probes belonging to groups Fn-1, Fn-2, and Fn-3. However, under stringent DNA hybridization conditions there was evidence of more genetic homogeneity within each group.
\end{abstract}

The genus Fusobacterium, as currently described in Bergey's Manual of Systematic Bacteriology (16), has undergone major revisions since it was first described $(5,6,11$, $12,15)$. The natural habitat of the type species, Fusobacterium nucleatum, appears to be oral cavities (3). This organism is frequently isolated from mucous membranes and from both supra- and subgingival dental plaque $(24,25)$. Several properties, such as cellular fatty acids $(1,9)$, peptidoglycan composition $(14,26)$, and bile sensitivity, distinguish $F$. nucleatum from nonoral species, such as Fusobacterium varium and Fusobacterium mortiferum (8). However, in spite of the apparent homogeniety among strains belonging to the species $F$. nucleatum, several workers have reported differences in morphology (13), serological properties (7), antibiotic susceptibilities (3), and both soluble protein and polypeptide profiles $(1,2,13)$.

In a preliminary study of the properties and distribution of glutamate dehydrogenase $(\mathrm{GDH})(4)$, we recently reported heterogeneity in GDH electrophoretic patterns in $F$. nucleatum. Whereas within other species electrophoretic bands were similar, three human isolates and one animal isolate of $F$. nucleatum possessed GDH bands that migrated differently (4). In this study, therefore, a large number of $F$. nucleatum strains that were isolated from normal and diseased sites in human oral cavities were subjected to a similar GDH electrophoretic analysis. Another important catabolic enzyme, 2-oxoglutarate reductase (OGR), was included to confirm the stability of the groups derived from the study of GDH electrophoretic mobilities. Deoxyribonucleic acid (DNA) base composition and DNA-DNA hybridization were used to assess the taxonomic status of the clusters formed.

\section{MATERIALS AND METHODS}

Bacterial strains. The following strains were used: $F$. nucleatum ATCC $25586^{\mathrm{T}}$ (T = type strain), NCTC 10953 (formerly "Fusobacterium polymorphum"), and NCTC

\footnotetext{
* Corresponding author.
}

11362 (formerly "Fusobacterium fusiforme"), as well as 30 clinical isolates from normal and diseased sites of human oral cavities.

Cultivation and identification. All of the strains were maintained by weekly subculture on $2.5 \%$ ( $\mathrm{vol} / \mathrm{vol})$ blood agar plates in an atmosphere containing $10 \%(\mathrm{vol} / \mathrm{vol}) \mathrm{CO}_{2}$ and $5 \%$ (vol/vol) $\mathrm{H}_{2}$ in $\mathrm{N}_{2}$ at $37^{\circ} \mathrm{C}$. Each strain was inoculated onto freshly prepared Columbia agar (Oxoid Ltd., London, England) supplemented with $6 \%$ horse blood and $0.1 \%$ vitamin $\mathrm{K}$ and was incubated anaerobically for $48 \mathrm{~h}$. A bacterial suspension corresponding to a McFarland no. 4 density standard was used to inoculate a RapID ANA Kit (API System, La Balme-Les-Grottes, France), and the strips were incubated aerobically at $37^{\circ} \mathrm{C}$ for $4 \mathrm{~h}$. Strains were identified as described by Murdoch et al. (17). The method used for acid end product analysis for culture supernatants has been described previously (8).

Preparation of cell-free extracts and enzyme electrophoresis. Cells were harvested from 2-day-old blood agar cultures and were suspended in $0.5 \mathrm{ml}$ of $0.1 \mathrm{M}$ tris(hydroxymethyl) aminomethane hydrochloride buffer $(\mathrm{pH}$ 8.5). Each cell suspension was shaken with Ballotini beads (grade 12) for 10 min in a Mickle tissue disintegrator at $4^{\circ} \mathrm{C}$. The suspension was centrifuged at $37,000 \times g$ for $10 \mathrm{~min}$, and the supernatants were electrophoresed as described previously (20). Electrophoresis was for $90 \mathrm{~min}$ at $15 \mathrm{~V} / \mathrm{cm}$ of gel in $0.04 \mathrm{M}$ barbitone-acetic acid buffer ( $\mathrm{pH} 8.6)$. GDH was visualized by using a solution of glutamate $(20 \mathrm{mg} / \mathrm{ml})$, nicotinamide adenine dinucleotide $(5 \mathrm{mg} / \mathrm{ml})$, phenazine methosulfate $(0.04 \mathrm{mg} / \mathrm{ml})$, and thiazolyl blue tetrazolium $(0.02 \mathrm{mg} / \mathrm{ml})$ in $0.1 \mathrm{M}$ tris(hydroxymethyl)aminomethane hydrochloride buffer ( $\mathrm{pH}$ 9.0). OGR was visualized by replacing the glutamate with a 2-hydroxyglutarate solution $(10 \mathrm{mg} / \mathrm{ml})$.

Isolation, purification, and base composition determination of DNA. DNAs from all strains were prepared as described previously (4). The DNA base composition was estimated from the melting temperature of the DNA in saline citrate (0.15 $\mathrm{M} \mathrm{NaCl}$ plus $0.015 \mathrm{M}$ trisodium citrate, $\mathrm{pH} 7.0$ ) by 
using a model 240 spectrophotometer (Gilford Instrument Laboratories, Inc., Oberlin, Ohio) and a model 2527 thermal programmer (Gilford) as described previously (21).

Preparation of labeled nucleic acid. All reference DNA preparations were dialyzed in deionized water for $48 \mathrm{~h}$ before labeling. For hybridization experiments, $3 \mu \mathrm{g}$ of each reference DNA was labeled in vitro with deoxy $\left[1^{\prime}, 2^{\prime}, 5\right.$ $\left.{ }^{3} \mathrm{H}\right]$ cytidine $5^{\prime}$-triphosphate by nick translation (10), using a commercial nick translation kit (Amersham Corp., Arlington Heights, Ill.). The reaction was terminated after $40 \mathrm{~min}$, and the DNA was separated from unincorporated nucleotides by gel exclusion chromatography through Sephadex G-50 and dialyzed in $0.42 \mathrm{M} \mathrm{NaCl}$. The DNA was sheared by sonication for $3 \mathrm{~min}$ with a $3-\mathrm{mm}$ probe at a power setting of 7 ( 3 to 4 A for three 10-s bursts; Soniprobe; Dawes Instruments, Ltd., London, England).

DNA-DNA hybridization. DNA homology experiments were performed as described previously (19), with minor modifications. The unlabeled DNAs to be used for all hybridizations with the labeled probe DNAs (from the three reference DNA preparations) were dialyzed in $0.42 \mathrm{M} \mathrm{NaCl}$ and sheared as described above to give a fragment size of approximately 500 base pairs. A reaction mixture containing $0.02 \mu \mathrm{g}$ of the labeled reference DNA and $20 \mu \mathrm{g}$ of unlabeled DNA was mixed in $200 \mu \mathrm{l}$ of $0.42 \mathrm{M} \mathrm{NaCl}$, and $200 \mu$ l of light paraffin oil was layered on top. The mixture was denatured for $10 \mathrm{~min}$ at $100^{\circ} \mathrm{C}$, and hybridization was allowed to proceed for $93 \mathrm{~h}$ at either $55^{\circ} \mathrm{C}$ (optimal hybridization) or $75^{\circ} \mathrm{C}$ (stringent conditions of hybridization). The tubes were then placed in an ice bath for 20 min to stop the reaction. S1 nuclease (100 U/ml; Sigma Chemical Co., Dorset, England) in a buffer containing $0.1 \mathrm{mM} \mathrm{ZnSO}_{4}, 0.15 \mathrm{M} \mathrm{NaCl}, 30 \mathrm{mM}$ sodium acetate ( $\mathrm{pH} 4.5)$, and $20 \mu \mathrm{g}$ of sheared and denatured calf thymus DNA (type V; Sigma) per ml was added to all tubes. The mixture was incubated for $20 \mathrm{~min}$ at $50^{\circ} \mathrm{C}$, precipitated with $10 \%$ trichloroacetic acid, and filtered on membrane filters (Schleicher \& Schuell, Dassel, Federal Republic of Germany). Cocktail T scintilation fluid (BDH, Essex, England) was added to the filters, which were counted with a model SL30 liquid scintilation counter (Intertechnique, Dover, N.J.). The level of hybridization was determined as a percentage of the value for the homologous reaction. The level of recovery of labeled DNA in the homologous reaction was $82 \%$. A correction was made for self-reassociation of labeled DNA by using calf thymus DNA as a control.

\section{RESULTS AND DISCUSSION}

The three reference strains and 30 clinical isolates used in this study were readily identified as $F$. nucleatum by using the RapID ANA system (API System). In addition, the metabolic end products of these organisms corresponded to those reported previously (8). Care was taken to distinguish these bacteria from other oral species, such as Fusobacterium sulci, Fusobacterium alocis, and Fusobacterium periodonticum, by using previously described tests $(2,23)$. Among the 33 strains of $F$. nucleatum tested, three groups were clearly discernible on the basis of GDH electrophoretic patterns. Furthermore, the compositions of the three GDH clusters formed were supported by the OGR electrophoretic mobility patterns (Fig. 1). The mobility clusters were designated groups Fn-1 (strains which had GDH and OGR mobilities of 0.8 and $1.8 \mathrm{~cm}$, respectively), Fn-2 (isolates which had GDH and OGR mobilities of 1.3 and $2.3 \mathrm{~cm}$, respectively), and Fn-3 (strains which had GDH and OGR mobilities of

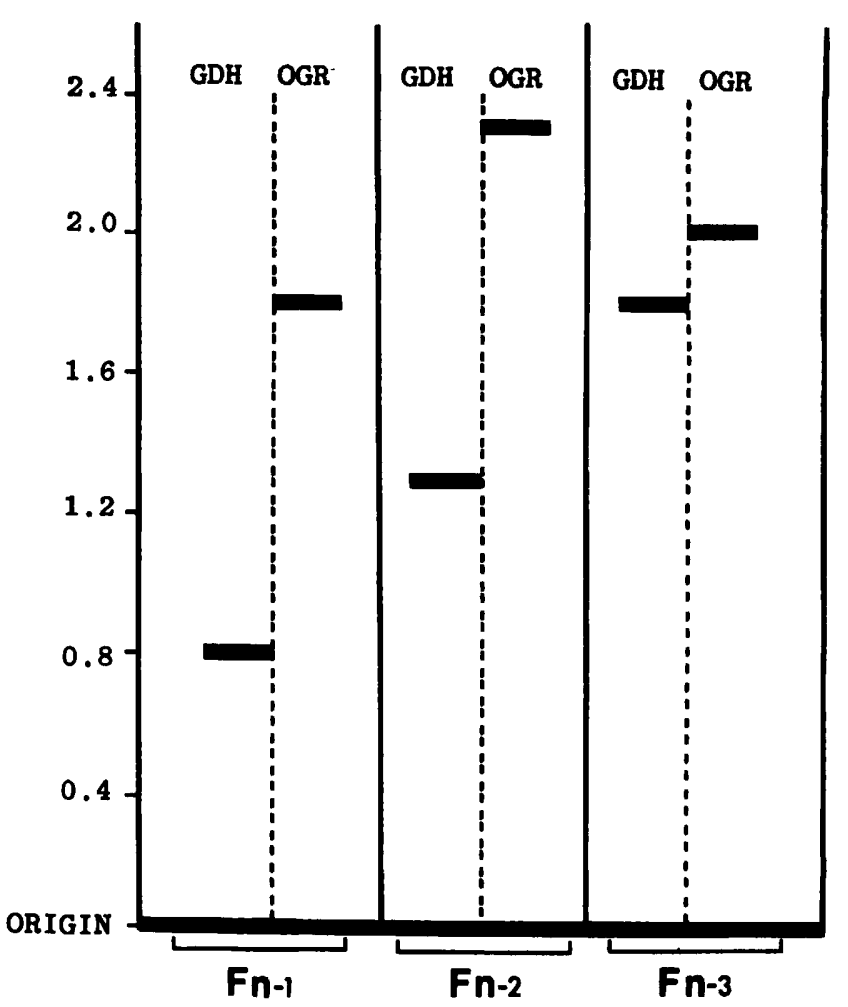

FIG. 1. Electrophoretic mobilities of GDH and OGR of $F . n u$ cleatum strains.

1.8 and $2.0 \mathrm{~cm}$, respectively) (Fig. 1). The variation in GDH and OGR electrophoretic mobilities within groups was minimal (ca. 1 to $2 \mathrm{~mm}$ ), and the patterns, which were tested on several occasions, were consistent. Group Fn-1 comprised 10 strains and included $F$. nucleatum ATCC $25586^{\mathrm{T}}$. Isolates which belonged to this group were readily identified by their distinctive morphology on blood agar plates, typical of that associated with $F$. nucleatum. After overnight growth, colonies were round, convex, and 0.5 to $1.0 \mathrm{~mm}$ in diameter and had a greyish white appearance. Group Fn-2 strains appeared to be the most frequently isolated organisms from human oral cavities. This group contained the previously described species " $F$. polymorphum" and consisted of 20 identical strains. After overnight culture, colonies on blood agar plates were characteristically round, convex, 1 to $2 \mathrm{~mm}$ in diameter, smooth, glistening, and entire. If cultures were incubated for more than 3 days, they became indistinguishable from group Fn-1 isolates. Group Fn-3 strains were the least commonly isolated strains of $F$. nucleatum. However, the four strains which belonged to this group were recognized by their distinctive colonial morphology; this group contained the previously described organism "F. fusiforme" $(5,6)$ NCTC 11362 (National Collection of Type Cultures, Central Public Health Laboratory, London, England). Colonies on blood agar plates were 1 to $3 \mathrm{~mm}$ in diameter and irregular and had a low cone shape with speckled surfaces, and pitting was frequently observed if the colonies were dislodged.

Despite the clear subdivision of $F$. nucleatum strains into three electrophoretic subgroups, DNA base composition determinations and DNA-DNA hybridization experiments indicated that human isolates of $F$. nucleatum belong to the same species. The guanine-plus-cytosine values ranged be- 
TABLE 1. DNA base compositions and DNA-DNA hybridization of $F$. nucleatum strains

\begin{tabular}{|c|c|c|c|c|c|c|c|}
\hline \multirow{3}{*}{ Strain } & \multirow{3}{*}{$\begin{array}{l}\text { Guanine-plus- } \\
\text { cytosine content } \\
\text { (mol\%) }\end{array}$} & \multicolumn{6}{|c|}{ \% Hybridization with $\left[{ }^{3} \mathrm{H}\right] \mathrm{DNA}$ from: } \\
\hline & & \multicolumn{2}{|c|}{ Strain ATCC $25586^{\mathrm{T}}$} & \multicolumn{2}{|c|}{ Strain NCTC 10953} & \multicolumn{2}{|c|}{ Strain 010} \\
\hline & & $\begin{array}{l}\text { Optimum } \\
\text { conditions } \\
\left(55^{\circ} \mathrm{C}\right)\end{array}$ & $\begin{array}{c}\text { Stringent } \\
\text { conditions } \\
\left(75^{\circ} \mathrm{C}\right)\end{array}$ & $\begin{array}{c}\text { Optimum } \\
\text { conditions } \\
\left(55^{\circ} \mathrm{C}\right)\end{array}$ & $\begin{array}{l}\text { Stringent } \\
\text { conditions } \\
\left(75^{\circ} \mathrm{C}\right)\end{array}$ & $\begin{array}{l}\text { Optimum } \\
\text { conditions } \\
\left(55^{\circ} \mathrm{C}\right)\end{array}$ & $\begin{array}{c}\text { Stringent } \\
\text { conditions } \\
\left(75^{\circ} \mathrm{C}\right)\end{array}$ \\
\hline \multicolumn{8}{|l|}{ Group Fn-1 } \\
\hline ATCC $25586^{\mathrm{T}}$ & 26 & 100 & 100 & 82 & 79 & 90 & 79 \\
\hline 1336 & 25 & 92 & 83 & 86 & 78 & 80 & 69 \\
\hline 1337 & 25 & 93 & 85 & 90 & 83 & 79 & 79 \\
\hline 338 & 26 & 97 & 90 & 88 & 80 & 80 & 71 \\
\hline 11 & 25 & 98 & 90 & 91 & 89 & 80 & 76 \\
\hline 13 & 25 & 99 & 89 & 92 & 79 & 80 & 73 \\
\hline 28 & 27 & 95 & 87 & 89 & 80 & 84 & 69 \\
\hline 78 & 27 & 96 & 84 & 88 & 79 & 82 & 70 \\
\hline D & 27 & 98 & 90 & 90 & 82 & 86 & 75 \\
\hline $\mathbf{A}$ & 27 & 92 & 86 & 92 & 80 & 90 & 80 \\
\hline Mean & & 96 & 88 & 89 & 81 & 83 & 74 \\
\hline \multicolumn{8}{|l|}{ Group Fn-2 } \\
\hline NCTC 10953 & 27 & 90 & 82 & 100 & 100 & 81 & 69 \\
\hline 21 & 26 & 90 & 82 & 97 & 90 & 87 & 77 \\
\hline 33 & 26 & 93 & 85 & 87 & 80 & 79 & 70 \\
\hline 38 & 25 & 97 & 88 & 85 & 79 & 90 & 83 \\
\hline 41 & 27 & 90 & 79 & 83 & 76 & 88 & 78 \\
\hline G & 26 & 93 & 80 & 96 & 81 & 85 & 80 \\
\hline 1446 & 25 & 90 & 82 & 87 & 75 & 90 & 79 \\
\hline 009 & 26 & 90 & 78 & 98 & 90 & 89 & 80 \\
\hline 337 & 26 & 93 & 77 & 97 & 90 & 94 & 80 \\
\hline 339 & 26 & 91 & 81 & 95 & 89 & 96 & 83 \\
\hline B109 & 25 & 93 & 80 & 93 & 88 & 90 & 76 \\
\hline 1445 & 27 & 97 & 89 & 90 & 87 & 80 & 70 \\
\hline 1407 & 25 & 95 & 90 & 82 & 74 & 83 & 69 \\
\hline 312 & 27 & 97 & 90 & 85 & 73 & 80 & 69 \\
\hline 304 & 27 & 95 & 87 & 90 & 80 & 79 & 64 \\
\hline 302 & 26 & 92 & 88 & 89 & 76 & 75 & 60 \\
\hline 318 & 25 & 94 & 87 & 85 & 70 & 73 & 60 \\
\hline 720 & 27 & 96 & 88 & 87 & 72 & 80 & 69 \\
\hline 708 & 25 & 97 & 88 & 86 & 79 & 76 & 65 \\
\hline 001 & 26 & 95 & 87 & 98 & 94 & 80 & 70 \\
\hline Mean & & 98 & 84 & 90 & 82 & 84 & 73 \\
\hline \multicolumn{8}{|l|}{ Group Fn-3 } \\
\hline NCTC 11362 & 26 & 90 & 80 & 82 & 71 & 87 & 80 \\
\hline 010 & 26 & 92 & 80 & 82 & 70 & 100 & 100 \\
\hline 45 & 26 & 87 & 79 & 80 & 73 & 90 & 78 \\
\hline 24 & 27 & 89 & 80 & 89 & 80 & 97 & 90 \\
\hline Mean & & 89 & 80 & 83 & 73 & 93 & 87 \\
\hline
\end{tabular}

tween 25 and $27 \mathrm{~mol} \%$ (Table 1), well within the limits of a clearly defined species. DNA-DNA hybridization experiments carried out against three reference DNA probes belonging to groups Fn-1, Fn-2, and Fn-3 confirmed the relatedness of these strains. Initially, DNA-DNA reassociation experiments were performed under optimal conditions $\left(55^{\circ} \mathrm{C}\right)$. The levels of DNA homology were high with each probe and ranged between 73 and $99 \%$ (Table 1). Under more stringent conditions, these values ranged between 60 and $90 \%$. Although we found high levels of DNA homology among all strains under stringent conditions, there was more genetic homogeneity within each of the three groups with their corresponding probes. For example, group Fn-1 strains hybridized with the group Fn-1 probe at levels between 83 and $90 \%$, whereas group Fn-3 strains exhibited between 69 and $80 \%$ homology with the same probe (Table 1 ).

Variations in electrophoretic mobilities occur due to differences in the net changes between enzyme molecules (22). A single amino acid substitution may alter the surface properties of a molecule and affect its electrophoretic mo- bility. However, several substitutions may also take place without affecting the electrophoretic properties of an enzyme (N. Dance and D. C. Watts, Biochem. J. 84p:114, 1962). Differences in electrophoretic migration patterns of enzymes may result from minor genetic alterations and may not reflect taxonomic identity, as in the present study. Often such differences reflect genetic heterogeneity $(18,20,21)$ and can be used to identify species which are otherwise difficult to differentiate. Since the electrophoretic patterns of GDH and OGR resulted in three clusters of the same strains, these subdivisions within $F$. nucleatum cannot be overlooked. Further studies involving $16 \mathrm{~S}$ ribonucleic acid sequencing are now in progress to study the phylogenetic relatedness of these organisms to other members of the Bacteroidaceae.

$F$. nucleatum strains form part of the normal flora of several sites within oral cavities (3). This species is now regarded as an important periodontal pathogen, and its association with acute necrotizing ulcerative gingivitis has long been recognized (28). As yet, no virulence determinants have been clearly identified, nor is it clear whether virulent 
and avirulent strains exist. Although most chemotaxonomic data indicate that $F$. nucleatum is a homogeneous species $(9$, 14,26 ), several studies of oral isolates to determine soluble protein or polypeptide patterns have indicated that there is considerable heterogeneity $(1,2,13)$. However, the electrophoretic patterns derived were too cumbersome and varied for clustering of isolates (1).

As GDH consistently had a distinctive migrating position within each group, strains could be readily assigned to one of the three clusters by using this enzyme pattern. However, the combined use of GDH and OGR may be helpful. To understand the role of $F$. nucleatum in its natural ecosystem, it may be necessary to recognize the diversity within the species. Tests used so far either have obscured this diversity or have been too complex to assess. The method which we describe provides a simple and reliable technique for studying the ecology of $F$. nucleatum.

\section{ACKNOWLEDGMENT}

S.E.G. acknowledges an ORS award for this work.

\section{LITERATURE CITED}

1. Calhoon, D. A., W. R. Mayberry, and J. Slots. 1983. Cellular fatty and soluble protein profiles of oral fusobacteria. J. Dent. Res. 62:1181-1185.

2. Cato, E. P., L. V. Moore, and W. E. C. Moore. 1983. Fusobacterium alocis sp. nov. and Fusobacterium sulci sp. nov. from the human gingival sulcus. Int. J. Syst. Bacteriol. 35:475-477.

3. Finegold, S. M., W. L. George, and M. E. Mulligan. 1985. Disease-a-month, p. 3-69. In N. J. Cotstonas, Jr. (ed.), Anaerobic infections, part 1, vol. 31. DM Yearbook Medical Publisher, Chicago.

4. Gharbia, S. E., and H. N. Shah. 1988. Characteristics of glutamate dehydrogenase, a new diagnostic marker for the genus Fusobacterium. J. Gen. Microbiol. 134:327-332.

5. Hine, M. K., and G. P. Berry. 1937. Morphological and cultural studies on the genus Fusiformis. J. Bacteriol. 34:517-534.

6. Hoffman, H. 1957. Genus Fusobacterium (Knorr 1922), p. 436-440. In R. S. Breed, E. G. D. Murray, and N. Smith (ed.), Bergey's manual of determinative bacteriology, 7th ed. The Williams \& Wilkins Co., Baltimore.

7. Hofstad, T. 1979. Serological responses to antigens of Bacteroidaceae. Microbiol. Rev, 43:103-115.

8. Holdeman, L. V., and W. E. C. Moore. 1972. Anaerobe laboratory manual. Anaerobe Laboratory, Virginia Polytechnic Institute and State University, Blacksburg.

9. Jantzen, E., and T. Hofstad. 1981. Fatty acids of Fusobacterium species: taxonomic implications. J. Gen. Microbiol. 123:163171.

10. Kelly, R. B., N. R. Cozzarelli, M. P. Deutscher, I. R. Lehman, and A. Kornberg. 1970. Enzymatic synthesis of deoxyribonucleic acid. XXXII. Replication of complex deoxyribonucleic acid by polymerase at a single strand break. J. Biol. Chem. 245:39-45.

11. Knorr, M. 1922. Uber die fusospirillane Symbiose, die Gattung Fusobacterium (K. B. Lehman) und Spirrilium sputigenum (Zugleich ein Beitrag Zur Bakteriologie der Mundhohle). I. Mitteilung: die Epidemiologie der fusospirillaren Symbiose, besonders der Flaut-Vincentschen Angina. Zentralbl. Bakteriol.
Parasitenkd. Infektionskr. Hyg. Abt. 1 Orig. 89:531-545.

12. Knorr, M. 1923 . Uber die fusospirillane Symbiose, die Gattung Fusobacterium (K. B. Lehman) und Spirrilium sputigenum. (Zugleich ein Beitrag Zur Bakteriologie der Mundhohle). It. Mitteilung: die Gattung Fusobacterium. Zentralbl. Bakteriol. Parasitenkd. Infektionskr. Hyg. Abt. 1 Orig. 89:4-22.

13. Love, D. N., E. P. Cato, J. L. Johnson, R. F. Jones, and M. Bailey. 1987. Deoxyribonucleic acid hybridization among strains of fusobacteria isolated from soft tissue infections of cats: comparison with human and animal type strains from oral and other sites. Int. J. Syst. Bacteriol. 37:23-26.

14. Miyagawa, E., R. Azuma, and T. Suto. 1981. Peptidoglycan composition of Gram-negative obligatory anaerobic rods. J. Gen. Appl. Microbiol. 27:199-208.

15. Moore, W. E. C., and L. V. Holdeman. 1974. Genus Fusobacterium (Knorr, 1922), p. 404-418. In R. E. Buchanan and N. E. Gibbons (ed.), Bergey's manual of determinative bacteriology, 8 th ed. The Williams \& Wilkins Co., Baltimore.

16. Moore, W. E. C., L. V. Holdeman, and W. Kelley. 1984. Genus II. Fusobacterium Knorr 1922, $4^{\mathrm{AL}}$, p. 631-637. In N. R. Krieg (ed.), Bergey's manual of systematic bacteriology, vol. 1. The Williams \& Wilkins Co., Baltimore.

17. Murdoch, D. A., I. J. Mitchelmore, R. A. Nash, J. M. Hardie, and S. Tabaqchali. 1988. Preformed enzyme profiles of reference strains of gram-positive anaerobic cocci. J. Med. Microbiol. 27:65-70

18. Shah, H. N., S. E. Gharbia, T. A. R. Al-Jalilii, R. A. Nash, and S. V. Seddon. 1987. Enzymes of diagnostic importance within the Bacteroidaceae: use as possible ecological markers. Microbiol. Health Dis. 1:115-121.

19. Shah, H. N., T. J. M. van Steenbergen, J. M. Hardie, and J. deGraaff. 1982. DNA base composition, DNA-DNA reassociation and isoelectric-focusing of proteins of strains designated Bacteroides oralis. FEMS Microbiol. Lett. 13:125-130.

20. Shah, H. N., and R. A. D. Williams. 1982. Dehydrogenase patterns in the taxonomy of Bacteroides. J. Gen. Microbiol. 128:2955-2965.

21. Shah, H. N., R. A. D. Williams, G. H. Bowden, and J. M. Hardie. 1976. Comparison of the biochemical properties of Bacteroides melaninogenicus from human dental plaque and other sites. J. Appl. Bacteriol. 41:473-492.

22. Shaw, C. R. 1965. Electrophoretic variation in enzymes. Science 149:936-942.

23. Slots, J., T. V. Potts, and P. A. Mashimo. 1983. Fusobacterium periodonticum, a new species from the human oral cavity. J. Dent. Res. 62:960-963.

24. Tanner, A. C. R., C. Haffer, G. T. Bratthall, R. A. Visconti, and S. S. Socransky. 1979. A study of the bacteria associated with advancing periodontitis in man. J. Clin. Periodontol. 6:278-307.

25. Van Palenstein Helderman, W. H. 1975. Total viable count and differential count of Vibrio (Campylobacter) sputorum, Fusobacterium nucleatum, Bacteroides ocharaceus and Veillonello in the inflamed and non-inflamed human gingival crevice. J. Periodontal Res. 10:294-305.

26. Vasstrand, E. N., H. B. Jansen, T. Miron, and T. Hofstad. 1981. Composition of peptidoglycan in Bacteroidaceae: determination and distribution of lanthionine. Infect. Immun. 36:114-122.

27. Veillon, A., and A. Zuber. 1898. Recherches sur quelques microbes strictement anaerobies et leur role en pathologie. Arch. Med. Exp. Anat. Pathol. 10:517-545.

28. Williams, B. L., R. M. Pantalone, and J. C. Sherris. 1976. Subgingival microflora and periodontitis. J. Periodontal Res. 11:1-18. 